\title{
"Geocaching" as a Method to Improve not only Spatial but also Social Skills: Results from a School Project
}

\author{
Heike ELLBRUNNER ${ }^{1}$, Friedrich BARNIKEL ${ }^{2}$ and Mark VETTER ${ }^{3}$ \\ ${ }^{1}$ Rupert-Egenberger-Schule/Förderzentrum Unterschleißheim / Germany \\ ${ }^{2}$ Städtisches Adolf-Weber-Gymnasium, München / Germany·friedrich.barnikel@awg.musin.de \\ ${ }^{3}$ Cartography and Geovisualisation, University of Applied Sciences, Karlsruhe / Germany
}

This contribution was double-blind reviewed as extended abstract.

\begin{abstract}
"Geocaching" is a proven way to bring fun into the Geosciences classroom. But in what way can geocaching improve spatial thinking and social skills alike? This contribution describes results from a project which is currently organized by two schools in the Greater Munich area. The scientific support comes from the University of Applied Sciences in Karlsruhe. Results from the ongoing project show significant improvement, not only in spatial, but also in social skills for the participating students. Especially weaker students gained self-assurance and respect among their peers, as well as learning to estimate distances and thus to be more punctual and self-confident, even in unknown environments.
\end{abstract}

\section{The Idea}

„You're nowhere unless you know where you are“ is a famous statement made by the former President of the U.S. National Geographic Society, Gilbert M. Grosvenor, in 1985. Grosvenor was keen on educating students about different forms of relationships, globally, economically and spatially. He was convinced that the basic skill to find orientation in the field is also coupled with finding orientation in one's life. Connecting these two aspects is the main aim of a geocaching-project devised by two teachers from different types of schools, one for special education/learning abilities ("Förderschule" in the Bavarian school system), and one for the upper secondary level ("Gymnasium"). Students from both school types (and other school types like „Mittelschule“, an intermediate secondary level school, and „Berufsschule“, a job training school) should have the opportunity to get in close contact with means of orientation (like maps and GPS devices), and to additionally practice social skills within their peer groups while doing the exercises.

\section{The Schools}

In Bavaria, students lacking certain abilities can attend the Förderschule. Here students get the chance to eventually earn a degree depending on their individual strengths (and weaknesses). Contact with students from Gymnasien, for instance, is scarce, and prejudices 
between these schools are the rule. The original plan of the authors was to get together students from both schools within the context of spatial thinking, thus connecting geographic and social skills. Projects like the one presented here have been regularly performed between the two first authors, and this new project was meant to take their kind of co-operation to a new level. Therefore, the schools have teamed up with the Professorship for Cartography and Geovisualisation of the Karlsruhe University of Applied Sciences. A few years ago, a co-operation between one of the authoring schools and the University of Erlangen had delivered first results in regard to spatial thinking (VETTER, BARNIKEL, PINGOLD \& PLÖTZ 2012). This geocaching-project can be seen not only as a mere sequel, but also as an assessment of the current development in the usage of GPS devices coupled with the acquirement of social skills.

\section{The Project}

\subsection{Expectations}

The project deals with several aspects connected to spatial sense. One aspect is the comparison between the use of analogue maps and the use of GPS receivers in regard to orientation. Another aspect is the question of whether spatial knowledge can be furthered at all by activities outside the classroom. Simple orientation activities like the ones mentioned by ZECHA (2009) can prepare the students for the project and keep them occupied when waiting for the other participating groups in the field. In addition to these orientation skills, the authors also expect a development within the social sector. How do students of different school-types perform, how do they deal with the challenges linked to the project, how do they see students from other school types and what may they gain personally from doing the activities?

\subsection{Activities}

"Geocaching" is an international treasure hunting game. So called "caches", hidden boxes containing a logbook and sometimes little things to swap, have to be located with the help of given co-ordinates (which are routed and found with GPS receivers - GPSrs - or analogue maps), or in some cases after solving some riddles (questions, quizzes) connected with the cache. The project takes place in two different study areas, namely, in a quarter within the city center of Munich (Untergiesing), and in a forested area on the northern outskirts of Munich (Hartelholz/Panzerwiese). In both areas students move around in small groups, some with GPSrs and some with specially prepared maps. In Untergiesing the students are requested to solve a multi-stage quiz ("Multicache") without a physical cache container, in the forest (Hartelholz) they have to find eight real cache containers.

\subsection{Project design}

Before doing the geocaching activities the students are asked to fill in a questionnaire designed exactly after the one used by VeTter, BARNikel, PINGOLD \& PlÖTz 2012 (to be able to compare findings of these two projects). Students are interviewed about their knowledge regarding digital maps, analogue maps, what media they use to orientate themselves etc. In München-Untergiesing the authors use a worksheet, also originally designed for the above mentioned study, only having changed some details to fit the new 
design in order to ensure that all students are capable of finding the objects, and also to have fun in the field. Then the students have to find six locations within the area, either with a GPSr (co-ordinates), or with a map (addresses are marked in the map), and answer some questions. It is basically a kind of scavenger hunt. To avoid possible contact between the different groups of two or three students, the study area is divided into two parts. After finding the answers to the questions, the students are asked to calculate a solution (in this case a one-digit figure) out of the different answers to make sure that all locations have been found.

In the forest Hartelholz the participants have to find eight "real" caches, again some with GPSrs (preferably those who previously worked with maps in Untergiesing), and some with maps (preferably those who previously worked with GPSrs in Untergiesing). The mapusers additionally receive some photos with the exact location of the caches (some of them e.g. hidden under autumn leaves etc.), so called "spoiler pictures", to make it easier for them to actually find the caches. The Hartelholz has also been divided into two adjacent smaller study areas to avoid contact between the different working groups. After finishing the project work, students finally have to fill in a second questionnaire for evaluation. The questions deal with distances and directions (north-south, east-west), which have to be estimated (see details in the article submitted to this year's AGIT by VETTER, ELLBRUNNER \& BARNIKEL (2014), where further scientific findings, especially regarding the characteristics of spatial skills gained in this geocaching-project, are compiled).

To help colleagues willing to participate in the project, several personal, institutional, and societal obstacles, as mentioned by KOLLER (2010) and HöHNLE, SCHUBERT, \& UPHUES (2011), have to be overcome. Therefore, the authors have devised different check lists, letter templates and basic information for teachers, headmasters, parents and students in advance.

\section{$4 \quad$ Experiences and First Results}

Between November 2013 and January 2014 more than 100 students between 13 and 20 years of age have already participated in the project. It is not surprising that the juveniles see the high tech GPS-devices as "bridges" to outdoor activities, as ZECHA (2012) points out. Accordingly the students by and large show remarkable abilities when dealing with the GPS-devices hitherto unknown to most of them. All in all the skills of dealing with maps have hugely improved, but that may have to do with the fact that maps are nowadays rarely used by students in general. The participating students so far had a lot of fun doing the exercises and in some cases even developed an informal competition amongst each other. They enjoyed using the high tech devices and the maps, and, especially in the cases of students from the Förderschule and the Berufsschule, got more self-assurance. Automatically some of the students took over a leading role and thereby influenced the social behavior among their peers. In some cases these students happened to be the weaker performers inside the classroom, but this time during the project they won acclamation from their peers and the teacher due to their lead in the field, a new experience for them.

Furthermore, spatial skills were improved by the project to also provide the students with more social stability, e.g. the ability to better estimate distances. This significantly improved the punctuality of students which is a crucial skill for their (future) professional 
careers. In addition to that we observed that only students who know their position and their target location, and who have experienced how to deal with range, speed, and directions can properly estimate distance and time needed. This may also help them to establish their position in society. All in all we could not find significant differences between students from different school types. We found out that the capability of using digital media for orientation is equally distributed among the students, and only depends on the age group.

A special aspect could be seen with Muslim female students. Some of them lead lives which are relatively dependent on male family members. Spatial experiences and skills help them not only to find better orientation in their hometown, but also to get to know places in town to give them support of any kind (free cultural offers, places to visit with the whole family etc.). That way they can win new freedom and independence.

The geocaching-project shows that students gather experiences and acquire skills that they would not get in ordinary classroom situations. The connection between spatial skills and social skills can be seen as a great asset to geosciences education in general and deserves further research.

\section{Outlook}

The project will continue until the end of spring 2014. During that time the authors will couple more students from different school-types to work together on the tasks, exchange their individual experiences and win social skills by not only experiencing themselves but also in reducing preoccupations between them.

\section{References}

Höhnle, S., Schubert, J. C. \& Uphues, R. (2011), Barriers to GI(S) use in schools - A comparison of international empirical results. In: JEKEL, T., KOLLER, A., DONERT, K. \& VOGLER, R. (Eds.), Learning with GI 2011 - Implementing Digital Earth in Education. Berlin/Offenbach, Wichmann, 124-133.

Koller, A. (2010), Geocaching - Ein Impuls für den GW-Unterricht?! GW-Unterricht, $119,58-64$.

Vetter, M., Barnikel, F., Pingold, M \& Plötz, R. (2012), Untersuchung zur Verwendung digitaler und analoger Karten im Erdkundeunterricht unter besonderer Berücksichtigung der Raumorientierung. In: HÜTTERMANN, A., KIRCHNER, P., SCHUlER, S. \& Drieling, K. (Eds.), Räumliche Orientierung, Karten und Geoinformation im Unterricht (Geographiedidaktische Forschungen, 49; Braunschweig), 227241.

VetTer, M., Ellbrunner, H. \& BARnikel, F. (2014), Untersuchung der räumlichen Orientierung bei Jugendlichen mit digitalen Karten. In: VogLER, R., CAR, A., STROBL, J. \& GRIESEBneR, G. (Eds.), GI_Forum 2014. Berlin/Offenbach, Wichmann (submitted).

ZECHA, S. (2009), Geocaching - Förderung der Orientierungskompetenz mit GPS. Praxis Geographie, 11/2009, 18-20.

ZECHA, S. (2012), Geocaching, a tool to support environmental education!? - An explorative study. Educational Research Journal, 1-2/2012, 177-188. 